Maas, J., Dillen, S.M.E. van, Verheij, R.A., Groenewegen, P.P. Social contacts as a possible mechanism behind the relation between green space and health. Health and Place: 2009, 15(2), 586-595

\begin{tabular}{|l|l|}
\hline $\begin{array}{l}\text { Postprint } \\
\text { Version }\end{array}$ & 1.0 \\
\hline $\begin{array}{l}\text { Journal website } \\
\text { Pubmed link }\end{array}$ & $\underline{\mathrm{http}: / / \mathrm{dx} \cdot \mathrm{http}: / / \text { www.org/10.1016/j.healthplace.2008.09.006 }}$ \\
\hline DOI & $10.1016 /$ j.healthplace.2008.09.006 \\
\hline
\end{tabular}

This is a NIVEL certified Post Print, more info at http://www.nivel.eu

\title{
Social contacts as a possible mechanism behind the relation between green space and health
}

\author{
JOLANDA MAas ${ }^{A}$, SONJA M.E. VAN DILlEN ${ }^{\mathrm{B}}$, ROBERT A. VERHEIJ ${ }^{\mathrm{A}}$ AND PETER P. \\ GROENEWEGEN $^{\mathrm{C}}$ \\ ${ }^{a}$ NIVEL (Netherlands Institute for Health Services Research), P.O. Box 1568, 3500 BN \\ Utrecht, The Netherlands \\ ${ }^{\mathrm{b}} \mathrm{CIZ}$, P.O. Box 232, NL-3970 AE Driebergen, The Netherlands \\ 'Department of Human Geography and Department of Sociology, Utrecht University, P.O. \\ Box 80115, NL-3508 TC Utrecht, The Netherlands
}

\begin{abstract}
This study explored whether social contacts are an underlying mechanism behind the relationship between green space and health. We measured social contacts and health in 10,089 residents of the Netherlands and calculated the percentage of green within 1 and a $3 \mathrm{~km}$ radius around the postal code coordinates for each individual's address. After adjustment for socio-economic and demographic characteristics, less green space in people's living environment coincided with feelings of loneliness and with perceived shortage of social support. Loneliness and perceived shortage of social support partly mediated the relation between green space and health.
\end{abstract}

\section{INTRODUCTION}

There is increasing attention and evidence for a positive relation between the amount of green space in the living environment and people's health and well-being. Several studies showed that more green space in the living environment of people is positively related to people's self-perceived health and leads to lower mortality risks (e.g. de Vries et al., 2003; Maas et al., 2006; Mitchell and Popham, 2007; Takano et al., 2002). However, little is known from these studies about the way in which green space exerts a beneficial effect on health. Several mechanisms could be underlying of which the following are most commonly mentioned: recovery from stress and attention fatigue, encouragement of physical activity and facilitation of social contact (de Vries et al., 2003; Groenewegen et al., 2006; Health Council of the Netherlands and Dutch Advisory Council for research on Spatial Planning, 2004; Maas et al., 2006). A large number of mainly experimental studies have produced strong evidence of the positive effect of nature on recovery from stress and attention fatigue (see e.g. [Hartig et al., 2003] and [Hartig et al., 1991]; Health Council of the Netherlands and Dutch Advisory Council for research on Spatial Planning, 2004; Kaplan and Kaplan, 1989). About other possible underlying mechanisms, such as social contacts, less is known. One review suggests green space might 'have beneficial effects on health in so far as green space promotes social contact, for example through green meeting places in neighbourhoods, group-based nature activities (e.g. walking or willow pollarding) and gardening (shared 
Maas, J., Dillen, S.M.E. van, Verheij, R.A., Groenewegen, P.P. Social contacts as a possible mechanism behind the relation between green space and health. Health and Place: 2009, 15(2), 586-595

gardens for the elderly and allotment gardens)' (Health Council of the Netherlands and Dutch Advisory Council for research on Spatial Planning, 2004). In this study, we aim to investigate whether social contacts are a possible mechanism behind the relation between green space and health.

Several terms have been used in studies of the health-enhancing components of social relationships, such as social support, social network and social integration (Berkman et al., 2000). In this paper, we prefer to use the container term social contacts for all these terms. Social contacts can take many forms, including having a conversation, undertaking joint activities and paying visits. It is widely recognised that social relationships can influence a variety of health outcomes (see e.g. Berkman et al., 2000; Hawe and Shiell, 2000). Persons actively involved in communities or socially engaged with others tend to live longer (Kawachi et al., 1997) and are healthier both physically as well as mentally (see e.g. Kawachi and Berkman, 2000; Leyden, 2003).

Meeting opportunities are important for the development of local communities and social ties with neighbours because people have to be able to meet to establish relationships (Flap and Völker, 2005; Völker et al., 2007). Most contact between neighbours will occur in places like local, recreation facilities, schools, churches and parks (Kuo et al., 1998; Völker et al., 2007). The presence of trees and grass in common spaces, as opposed to barren common spaces, may attract residents to outdoor spaces, thereby leading to more frequent contacts among neighbours (Coley et al., 1997). Natural settings in common space are attractive because they can for example provide shadow, privacy and sound buffering from surrounding environments and they could have restorative effects (Coley et al., 1997; Hartig et al., 2003; Kaplan and Kaplan, 1989). Three closely related studies, performed by the same research group in an underprivileged area of Chicago, provide indication of a positive relation between the presence of green public facilities and social ties (Coley et al., 1997; Kuo et al., 1998; Kweon et al., 1998).

Coley et al. (1997) investigated the link between the use of outdoor public spaces and the presence, number and location of trees. They found that the presence of trees 'consistently predicted greater use of outdoor spaces by all people, young and older, as well as groupings of people consisting of both youth and adults together'(Coley et al., 1997). Furthermore, they found that 'the amount of time residents spent in common space was strongly predicted by the presence, location and number of trees' (Coley et al., 1997). Kuo et al. (1998) took this line of research to the next level and studied whether greener neighbourhoods give rise to stronger neighbourhood social ties. They found that levels of vegetation predict both use of common spaces and the strength of neighbourhood social ties. Moreover, they found that use of common spaces mediated the relation between vegetation and neighbourhood social ties (Kuo et al., 1998).

Kweon et al. (1998) subsequently investigated the relationship between older adults' exposure to nearby green common spaces and their level of social integration and attachment to local community. They found modest relationships between the use of green outdoor common space and the strength of neighbourhood social ties and sense of community for older adult residents of inner-city neighbourhoods.

Overall, these studies broadened our understanding of the importance of green space for neighbourhood social ties. However, it is unknown whether these results also apply to other settings. The studies were conducted in highly deprived urban areas where green elements were very scarce. The question is whether these relationships will also be found in other, richer and greener neighbourhoods.

Besides offering meeting opportunities green spaces can also promote a general sense of community. According to Kim and Kaplan (2004), sense of community of residents is strengthened when they feel at home (community attachment), have bonds with others, feel a sense of connection with the place (community identity) and have access for local exploration (pedestrianism). An empirical investigation showed that natural features and open spaces were the most important physical features which contribute to these four 
Maas, J., Dillen, S.M.E. van, Verheij, R.A., Groenewegen, P.P. Social contacts as a possible mechanism behind the relation between green space and health. Health and Place: 2009, 15(2), 586-595

domains of sense of community. Natural features can promote a sense of community by increasing feelings of emotional attachment to a neighbourhood and people's identity with a place, which in turn could decrease feelings of loneliness and increases social support (Pretty et al., 1994; Prezza et al., 2001). Therefore, it is interesting not only to investigate the direct relation between green space and contact with neighbours but also with feelings of loneliness and social support.

A few studies have addressed the relation between green space and social contacts and sense of community. Flap and Völker (2005) showed that Dutch neighbourhoods with more open green space and recreational facilities, promote a sense of community. A study by Ewert and Heywood conducted in the US (1991) showed that undertaking activities in natural environments appeared to have stimulating effects on social contacts and social cohesion. The results of a study by Leyden (2003) show that people in Ireland in walkable neighbourhoods, which are among other things characterised by the availability of local parks, are "more likely to know their neighbours, to participate politically, to trust others, and to be involved socially' ( $p$ 1550). On the other hand, in Western Australia, Wood et al. (2007) did not find a relation between distance to park from the respondents home and social capital.

Overall, there are several indications of a positive relation between green space and social contacts. The aim of this study is to investigate whether social contacts are a possible factor mediating the relation between green space and health.

More specifically, the following questions will be answered:

1. Is the amount of green space in people's living environment related to people's health?

2. Do people with more social contacts feel healthier?

3. Is the amount of green space in people's living environment related to social contacts?

4. Can the relation between green space and social contacts explain the relation between green space and health?

To gain more insight in the relation between social contacts and green space, we will analyse it for different subgroups. First of all, the relation will be analysed for different age groups to find out whether the relation is stronger for children and elderly, who have fewer resources to develop and maintain social ties that are further away from their homes. As a consequence of the more limited mobility of children and elderly, they rely more on nearby neighbours and their neighbourhood to support their needs (e.g. Kweon et al., 1998). Furthermore, the relation will be analysed for different social economic status groups to find out whether groups with a lower social economic status benefit more from green space in their living environment. Finally, we will investigate whether the relation is the same for urban and rural areas. Neighbourhoods in urban areas are more likely to be deteriorated, more often have to deal with vandalism, have a less strong local community and lower levels of social control (Flap and Völker, 2005; Steenbekkers et al., 2006). People living in rural areas more often socialize with their neighbours, less often experience nuisance from their neighbours (Steenbekkers et al., 2006) and have more social contacts in general (de Jong Gierveld, 1998). Overall, however, levels of deterioration are relatively low in the Netherlands.

\section{METHODS}

\section{Data}

The data for this study were derived from two different datasets that were combined for this study. The health data and data on social contacts were collected within the framework of the second Dutch National Survey of General Practice (DNSGP-2), conducted in the Netherlands in 2001. The DNSGP-2 included a nationwide representative sample of 104 general practices with approximately 400,000 people on their list, who were a good representation of the Dutch population in terms of age, gender and type of health insurance (Westert et al., 2005). 
Maas, J., Dillen, S.M.E. van, Verheij, R.A., Groenewegen, P.P. Social contacts as a possible mechanism behind the relation between green space and health. Health and Place: 2009, 15(2), 586-595

As part of the DNSGP-2 a random sample of 12,699 people participated in a health interview survey (response rate 64.5\%). Questionnaires were administered by trained interviewers during a face-to-face interview. To avoid seasonal patterns in morbidity, all interviews were carried out within 12 months in 2001 and distributed equally across all four seasons. People aged between 12 and 17 were interviewed, with one parent present. Privacy of the participating persons is guaranteed and in accordance with Dutch legislation, and the study was approved by the Dutch Data Protection Authority. Patients were informed about the study prior to data collection (Westert et al., 2005). The socio-demographic characteristics of the respondents were highly comparable to those of the total Dutch population, although men, younger age groups and migrants were slightly underrepresented (Westert et al., 2005).

Environmental data were derived from the National Land Cover Classification database (LGN4), which contains the dominant type of land use of each $25 \mathrm{~m} \times 25 \mathrm{~m}$ grid cell in the whole of the Netherlands in 2001 (Thunissen and De Wit, 2000). The two datasets were matched on the basis of the $\mathrm{x}$ and $\mathrm{y}$ coordinates of the respondent's six character postal code (on average about 15-20 households have the same six character postal code). Only respondents who had valid responses on the relevant variables were included, leaving 10,089 respondents.

\section{Measures}

\section{Self-reported health indicators}

We used three global health indicators that have shown to be positively related with the amount of green space in the living environment in a study by De Vries et al. (2003):

1. Perceived general health-Measured on a five-point scale, running from 'excellent' (1) to 'bad' (5). For our purposes the scores were dichotomised with scores from good to excellent classified as healthy (1). This kind of operationalisation has shown to be valid and predictive of health indicators in numerous studies (Rütten et al., 2001; Simons, 2002).

2. Number of health complaints (maximum 43) experienced in the last 14 days (e.g. headache, coughing, nausea and lower back pain) (Foets and Van der Velden, 1990).

3. Self-rated propensity to psychiatric morbidity-Measured with the Dutch 12-item version of the General Health Questionnaire (GHQ-12) (Goldberg, 1972; Koeter and Ormel, 1991). This variable was dichotomised: scores of 2 and higher were classified as an increased risk of psychopathology.

\section{Social contacts}

We used the following measures of social contacts:

1. Loneliness-Measured using six items that were based on the UCLA loneliness scale, e.g. 'I feel part of a group friends', I feel isolated from others', 'There are people who really understand me' (Russell, 1996). A summary score counted the degree of loneliness [possible score range 6-18], with a higher score representing a higher degree of loneliness. The scale had an internal reliability (Cronbach's alpha) of 0.64 .

2. Social support-Measured with the social support list (SSL), which has shown good construct validity and high reliability (Bridges et al., 2002; Van Sonderen, 1993a). The SSL measures among other things the interactions (SSL-I) and discrepancies (SSL-D) that people experience in receiving social support from their direct environment. Each list originally consists of 34 items which form six subscales. Only questions related to three subscales (in total 19 items) were included in the health interview to shorten the length of the survey, namely emotional support with problems (eight items), instrumental interactions (seven items) and informative support (four items) (Van Sonderen, 1993b). For this study, we investigated both the number of supportive interactions people receive (using SSL-I) and the shortage of social support (using the SSL-D). 
Maas, J., Dillen, S.M.E. van, Verheij, R.A., Groenewegen, P.P. Social contacts as a possible mechanism behind the relation between green space and health. Health and Place: 2009, 15(2), 586-595

The number of supportive interactions: The SSL-I measures the number of supportive interactions people receive from their social support network. The response categories are as follows: seldom/never (1); now and then (2); regularly (3); and often (4). A total score on the SSL-I was measured by summing up the scores on the 19 items, the higher the score the more social support (Cronbach's alpha $=0.85$ ).

Shortage of social support: The SSL-D represents the subjective experience of mismatches between the received and desired frequency of receiving social support. The response categories are (1) I miss it, I would like it to happen more often (2) I don't really miss it, but it would be nice if it happened a bit more often (3) just right, I would not want it to happen more or less often (4) it happens too often, it would be nice if it happened less often. The focus of this study was on the perceived lack of social support, that is 'I miss it'. Following the instructions for using this scale, the first category was recoded into value 3 and the second category kept value 2 . The latter two response categories (categories 3 and 4 ) both received value 1. A higher score on the scale thus equals a larger shortage of social support. A total score on the SSL-D was measured by summing up the scores on the 19 items (Cronbach's alpha $=0.86$ ).

Only a random sample of about half the study population $(n=4944)$ has been asked questions concerning social support to shorten the length of the questionnaire. Furthermore, only the respondents who filled in all questions were included (excluded 102 respondents).

3. Contact with neighbours and friends in the neighbourhood-Respondents were asked how often they had contact with their neighbours or friends in the neighbourhood. Because the answers were not normally distributed, we decided to make a dummy variable on whether people often contacted neighbours and friends in the neighbourhood (more than 3 time per week or 1-3 times per week $=1)$ ) or not often (1-3 times per month, 4-11 times per year, maximally 3 times a year $=0$ ). Only a random sample of about half the study population $(n=4635)$ has been asked this question in order to shorten the length of the questionnaire. Some of the respondents $(n=228)$ stated that this question was not applicable for them. We left these respondents out of the analysis leaving 4407 respondents for this analysis.

\section{Characteristics of respondents' living environment}

The following two indicators were used to measure characteristics of the respondents' living environment:

1. Percentage of green space-Information on the environmental characteristics was derived from the LGN4 database. The LGN4 database discriminates 39 land-use classes including crop types, forest types, water, various urban classes and semi-natural classes and has been proven to be valid, accurate and reliable (De Wit and Clevers, 2004; Thunissen and De Wit, 2000). The total percentage of green space in the respondents' living environment was measured within 1 and $3 \mathrm{~km}$ radius around a respondent's home, to see whether green space close by has a stronger or weaker effect than green space further away. The total percentage of green space includes all urban green, agricultural green, forests and nature conservation areas. Grid cells of $25 \mathrm{~m} \times 25 \mathrm{~m}$ are regarded as green space in the dataset if green space has a dominant position. Gardens and small-scale green spaces, like for instance, street trees and green roadsides are not regarded as green space in our study because they had no dominant position in the grid cell.

2. Urbanicity-Another environmental characteristic is urbanicity. This variable consists of five categories ranging from very strongly urban (1) to non-urban (5), and was measured at municipal level. The indicator is based on the number of households $/ \mathrm{km}^{2}$ and is widely used in the Netherlands (Den Dulk et al., 1992).

\section{Demographic and socio-economic characteristics}

Network research reveals that social networks or social interaction of people with different background characteristics differ considerably. Women tend to have larger and more 
Maas, J., Dillen, S.M.E. van, Verheij, R.A., Groenewegen, P.P. Social contacts as a possible mechanism behind the relation between green space and health. Health and Place: 2009, 15(2), 586-595

intimate social networks (Kendler et al., 2005). The number of friends and the frequency of social contacts decline with age (van Tilburg, 1998). Furthermore, people with higher education and higher income levels have larger networks than people with lower education and income levels (Tijhuis, 1994). Because social networks and health differ according to people's background characteristics, we took several of these characteristics into account:

1. Demographic characteristics-The demographic characteristics taken into account were gender (female=1) and age (years). To find out whether the relation between social contacts and green space differed for different age groups, age was divided into five categories (viz. children (aged 12-17 years), youths (aged 18-25 years), young adults (aged 26-40 years), older adults (aged 41-65 years), elderly (aged 65+)).

2. Socio-economic status (SES) was measured by level of education (divided into four dummy variables categories: unknown, low, middle and high) and household income (divided into four dummy variables: income unknown, high income (net monthly income $>2450$ euro), middle income (net monthly income between 1350 and 2450 euro) and low income (net monthly income $<1350$ euro)). Level of education and income was categorised because of the non-linear relation with some of the dependent variables. We included the categories 'unknown' for level of education and income in order to avoid excessive drop-out of respondents.

3. Size of the respondent's household-Because the size of the respondent's household also influences the level of social contacts of the respondent (e.g. Tijhuis, 1994), we included a variable measuring the size of the respondent's household in the analysis concerning the relation between green space and the different forms of social contacts.

\section{[TABLE 1].}

\section{Statistical analyses}

The relation between the amount of green space, social contacts and health was assessed by multilevel regression analyses, controlling for socio-economic and demographic characteristics and urbanicity. The multilevel analyses were performed with MLwiN. We included two levels, viz. practice and individual level, because the data of individuals were gathered through general practices and therefore individuals clustered within practices. The postcode level was not included because there were hardly any people from the same six character postal code in the dataset. The independent variables, including the percentage of green space, were centred on the average which reduces chances of multicollinearity (Draper and Smith, 1998). The results reflect the individual level. Multilevel logistic regression analysis was used in case the dependent variable was a dichotomy. Because we wanted to compare the relation for different levels of urbanicity and different subgroups, we used several models in which we included interaction effects between the urbanicity or subgroup variable and the green indicator.

As we want to investigate whether social contacts mediate the relation between green space and health, we used Baron and Kenny's (1986) procedure for establishing whether mediation has occurred. To show mediation, the independent variable must significantly influence the potential mediator, the mediator must have a significant relationship with the dependent variable, and the relationship between the independent variable and dependent variable should be eliminated (full mediation) or weakened (partial mediation) when the mediator is controlled for. We used a series of multilevel (logistic) regression equations and the Sobel test (Preacher and Hayes, 2004 K.J. Preacher and A.F. Hayes, SPSS and SAS procedures for estimation indirect effects in simple mediation models, Behavior Research Methods, Instruments, and Computers 34 (4) (2004), pp. 717-731. View Record in Scopus | Cited By in Scopus (427)Preacher and Hayes, 2004) to test for mediation. 
Maas, J., Dillen, S.M.E. van, Verheij, R.A., Groenewegen, P.P. Social contacts as a possible mechanism behind the relation between green space and health. Health and Place: 2009, 15(2), 586-595

\section{RESULTS}

\section{Relation between green space and health}

We investigated the relationship between green space and health both with our total sample and with the subsample that provided data on social support and contact with neighbours.

We first investigated the relation for the percentage of green space in a $1 \mathrm{~km}$ radius around people's home. Subsequently, we investigated the relation for the percentage of green space in a $3 \mathrm{~km}$ radius around people's home. Overall, people with more green space in their living environment feel healthier, have experienced a lower number of health complaints in the last 14 days and have lower self-rated propensity for psychiatric morbidity (Table 2, models 1 and 2). The relation between green space and the different health indicators was stronger and more consistent for the percentage of green space in a $1 \mathrm{~km}$ radius around people's home. In the dataset with a smaller sample size, there was no relation between the percentage of green space in a $3 \mathrm{~km}$ radius around people's home and the three health indicators (Table 2, models 3 and 4$)$.

\section{[TABLE 2]}

\section{Relation between social contacts and health}

Whether or not people often have contact with neighbours or friends in the neighbourhood are not related to any of the health indicators (Table 2, model 5). Concerning the relation between loneliness and health, Table 2 shows that people who feel less lonely have a better self-perceived health, experienced fewer health complaints and have a lower self-rated propensity for psychiatric morbidity (Table 2, model 6). People who report a larger number of supportive interactions feel less healthy, report a higher number of health complaints and have a higher self-rated propensity for psychiatric morbidity (Table 2, model 7). People who experience a larger shortage of social support feel less healthy, report a higher number of health complaints and have a higher self-rated propensity for psychiatric morbidity (Table 2 , model 8).

\section{Relation between green space and social contacts}

\section{Loneliness}

For all measures of social contact, we investigated in separate models whether they were related to the percentage of green space in a 1 or $3 \mathrm{~km}$ radius. Table $3 \mathrm{a}$ shows that there is a significant relation between both the percentage of green in 1 and in $3 \mathrm{~km}$ radii around people's home and their feelings of loneliness. People with more green space in their living environment feel less lonely.

\section{[TABLE 3A AND B]}

The different models in Table 4 show the results for the relation between green space and loneliness for different subgroups. The subgroup analyses show that there is a relation between green space and loneliness in strongly urban municipalities, for children ( 1 and $3 \mathrm{~km})$, young adults $(1$ and $3 \mathrm{~km})$, adults $(3 \mathrm{~km})$, elderly $(3 \mathrm{~km})$, lower educated people and for people with a low income ( 1 and $3 \mathrm{~km})$ (see Table 4$)$.

\section{[TABLE 4]}

\section{Social support}

No significant relations are found between the percentage of green space in the living environment and the number of supportive interactions respondents receive from their social support network (see Table 3a). However, people with more green space in a $1 \mathrm{~km}$ radius around their home experience less shortage of social support (see Table 3a). Our subgroup 
Maas, J., Dillen, S.M.E. van, Verheij, R.A., Groenewegen, P.P. Social contacts as a possible mechanism behind the relation between green space and health. Health and Place: 2009, 15(2), 586-595

analyses show that this relation is apparent in strongly urban municipalities, for children, youth, elderly and for people with a low income (see Table 4). There was no significant relation between the amount of green space in a $3 \mathrm{~km}$ radius around people's home and shortage of social support (see Table 3b).

\section{Contact with neighbours or friends in the neighbourhood}

Although there is no relation between whether or not people often contact neighbours and friends in the neighbourhood and the health indicators, we did want to investigate whether there is a relation between green space and this indicator for social contacts. There appeared to be no significant relation between the percentage of green space and whether or not people often contacted neighbours or friends in the neighbourhood (see Table 3).

Loneliness and shortage of social support as a possible mechanism behind the relation between green space and health

Only for loneliness $(1$ and $3 \mathrm{~km})$ and shortage of social support $(1 \mathrm{~km})$ all requirements for testing mediation are met, since for the other mediators no relation was found with the percentage of green space in the living environment. Therefore, we only tested whether loneliness or shortage of social support mediate the relation between green space and the different health indicators.

\section{Green space, loneliness and health}

Table 5 shows the results for loneliness. The results show that adding loneliness to the model slightly influences the relation between the percentage of green space and perceived general health, the number of health complaints in the last 14 days and people's self-rated propensity to psychiatric morbidity. This indicates partial mediation. To test whether loneliness mediates the relation between green space and the different health indicators we conducted a Sobel test. Loneliness appears to partially mediate the relation between green space and self-perceived health $(1 \mathrm{~km}: \mathrm{z}=6.26, \mathrm{p}<0.001 / 3 \mathrm{~km}: \mathrm{z}=7.43, \mathrm{p}<0.001)$, number of health complaints $(1 \mathrm{~km}: \mathrm{z}=-6.22, \mathrm{p}<0.001 / 3 \mathrm{~km}: \mathrm{z}=7.36, \mathrm{p}<0.001)$ and self-reported propensity to psychiatric morbidity $(1 \mathrm{~km}: \mathrm{z}=-5.57, \mathrm{p}<0.001 / 3 \mathrm{~km}: \mathrm{z}=6.89, \mathrm{p}<0.001)$.

\section{[TABLE 5]}

\section{Green space, shortage of social support and health}

Table 6 shows the results for the triad between shortage of social support, the amount of green space in a $1 \mathrm{~km}$ radius and the number of health complaints and the self-rated propensity for psychiatric morbidity. The triad for green space, shortage of social support and self-perceived health was not investigated, because the analyses on the relation between green space and self-perceived health (see Table 2) showed that there was no significant relation between the percentage of green space and self-perceived general health for the smaller sample.

\section{[TABLE 6]}

Concerning the number of health complaints our analyses show that adding shortage of social support to the model slightly diminishes the relation between the amount of green space in a $1 \mathrm{~km}$ radius and the number of reported health complaints in the last 14 days. Shortage of social support appears to partially mediate between the amount of green space in a $1 \mathrm{~km}$ radius and number of health complaints $(1 \mathrm{~km}$ : Sobel $=-0.0039, \mathrm{z}=-6.35$, $\mathrm{p}<0.001 / 3 \mathrm{~km}$ Sobel $=-0.0036, \mathrm{z}=5.25, \mathrm{p}<0.001)$.

The analyses concerning people's self-rated propensity for psychiatric morbidity show that adding shortage of social support to the model renders the percentage of green space in a $1 \mathrm{~km}$ radius insignificant. Shortage of social support mediated the relation between the 
Maas, J., Dillen, S.M.E. van, Verheij, R.A., Groenewegen, P.P. Social contacts as a possible mechanism behind the relation between green space and health. Health and Place: 2009, 15(2), 586-595

percentage of green space in a $1 \mathrm{~km}$ radius and self-rated propensity for psychiatric morbidity $(1 \mathrm{~km}$ : Sobel $=-0.0004, \mathrm{z}=-6.19, \mathrm{p}<0.001 / 3 \mathrm{~km}$ Sobel $=-0.0004, \mathrm{z}=5.30, \mathrm{p}<0.001)$.

\section{DISCUSSION}

This study examined whether social contacts mediate the relation between green space and health. We started by investigating the relation between green space and different health indicators. Our study shows that people with more green space in $1 \mathrm{~km}$ radius around their home have better self-perceived health, have experienced fewer health complaints in the last 14 days and have a lower self-rated propensity for psychiatric morbidity. This is consistent with the studies by De Vries et al. (2003) and Maas et al. (2006), who used other datasets to investigate the relation between green space and health, and strengthens the evidence for a positive relation between the amount of green space in a $1 \mathrm{~km}$ radius around people's home and health. However, although significant relations between the amount of green space in a $3 \mathrm{~km}$ radius around people's home and health have been found in the studies by De Vries et al. (2003) and Maas et al. (2006), this study did not find a consistent significant relation, indicating that green space closer to home might be more important for people's health.

Concerning the relation between social contacts and health our results showed that both loneliness and experienced shortage of social support are negatively related to people's selfperceived health, the number of health complaints and the self-rated propensity for psychiatric morbidity. This is consistent with other studies which also find a positive relation between social isolation, social support and health (e.g. House et al., 1988; Kawachi et al., 1997; Kendler et al., 2005; van Oostrom et al., 1995). There was no relation between whether or not people had frequent contacts with neighbours and any of the three health indicators. We found a negative relation between the number of supportive interactions and the health indicators; people with more health problems received more social support. This negative relationship between the number of supportive interaction and health has also been found in other studies (Tijhuis, 1994; Van Sonderen and Ormel, 1997) and may be due to the higher need for social support of unhealthy people.

\section{Green space and social contacts}

Concerning the relation between green space and social contact, our results show that people with more green space in their living environment feel less lonely and experience less shortage of social support, but they did not have more contact with neighbours or friends in the neighbourhood and they did not receive more social support. This suggests that the relation between green space and social contacts has more to do with the fact that green spaces can strengthen sense of community via place attachment and place identity of its residents, than with actual contacts with neighbours. Further research is needed to investigate whether the relation between green space and social contacts is mediated by the four domains of sense of community.

Only green space close to home appeared to be related to social support. The subgroup analyses show that the relation between green space and loneliness and the relation between green space and shortage of social support was strongest in the strongly urban areas. Furthermore, as we hypothesised, both relations appeared to be strongest for children and elderly who, as a consequence of limited mobility rely more on their neighbourhood to support their needs (Kweon et al., 1998). Finally, the relation was strongest for people with a low income or a low level of education, indicating that they benefit most of green space in their living environment for their social contacts. Apparently, the amount of green space in the living environment is less important for social contacts of people with a high SES. The studies conducted in Chicago also found a relation between social ties and the presence of green public space for people with a low SES (Coley et al., 1997; Kuo et al., 1998; Kweon et al., 1998). However, because these studies were conducted in an underprivileged area in Chicago, no comparison could be made between the relation for lower and higher SESgroups. 
Maas, J., Dillen, S.M.E. van, Verheij, R.A., Groenewegen, P.P. Social contacts as a possible mechanism behind the relation between green space and health. Health and Place: 2009, 15(2), 586-595

A direct comparison between the results of this study and the studies conducted in Chicago is not possible. First of all, because of the different settings in which the studies are performed. Unlike the Chicago studies, which were performed in underprivileged areas, this study was performed on a representative sample of the Netherlands and includes all kinds of neighbourhoods and people with different backgrounds. Furthermore, the Chicago studies focus on specific small-scale green space close to people's home, while in this study smallscale green space like for instance gardens, street trees, playgrounds with trees and green roadsides are not seen as green spaces, as a results of restrictions of the database we used.

\section{Social contacts as an explanation for the relation between green space and health}

Because only loneliness and shortage of social support were related to the amount of green space in the living environment, we only investigated whether loneliness and a smaller shortage of social support could explain the relation between green space and health.

We used three different health indicators to investigate this. Both loneliness and shortage of social support partially mediated the relation between green space and the different health indicators. Shortage of social support even completely mediated the relation between green space and self-rated propensity for psychiatric morbidity.

\section{Strengths and limitations}

Only few studies have investigated the relation between social contacts and green space (e.g. Ewert and Heywood, 1991; Kuo et al., 1998) and, as far as we know, there are no other studies which also investigated the triad between green space, social contacts and different health indicators.

The data on health and social contacts were derived from a different database then the data on green space; consequently, there is no single source bias.

For our study, we used objective environmental measures. Objective environmental measures reduce the risks of respondent bias. However, subjective environmental measures can also provide important information. People's perception of green spaces may, in fact, motivate their behaviour more than the actual amount of available green space. Unsafe green spaces or green spaces with a low quality will be avoided by people. Thus, combining objective measures and measures of individual's perception will improve our understanding of how the green environment affects social contacts (Coley et al., 1997; Kuo et al., 1998; Kweon et al., 1998).

Although the data used for this study have important advantages, they also have a few shortcomings. First of all, our data on green space, although assessed on a small scale, does not take small green spaces in the living environment into account. Only green space that has a dominant position in the $25 \mathrm{~m} \times 25 \mathrm{~m}$ grid cell will be regarded as green space in the dataset. Small-scale green spaces, which have been shown to influence the strength of neighbourhood social ties and informal social contacts among neighbours in underprivileged areas in Chicago, are not regarded as green space in our study because they had no dominant position in the grid cell.

Secondly, because of the cross-sectional design of the study, it is not possible to make a statement about the direction of causation. It is possible that people who like to have more social contacts chose to live in greener environments because these environments offer meeting opportunities.

A third limitation of the study is that we did not know if the social contacts of people took place in green environments. Future research should focus on whether green space in different environments is actually used as a place to meet others.

Some possibly important control variables could not be taken into account. Besides meeting opportunities, several other conditions are important for the development of local communities and social ties, namely 'individual motivation to invest in others in the group, alternatives to realize individual goals and interdependencies' (Flap and Völker, 2005; Völker et al., 2007), community attachment, community identity, social interaction, pedestrianism (Kim and Kaplan, 2004). In this study, we only focussed on meeting 
Maas, J., Dillen, S.M.E. van, Verheij, R.A., Groenewegen, P.P. Social contacts as a possible mechanism behind the relation between green space and health. Health and Place: 2009, 15(2), 586-595

opportunities in the form of a green environment. It remains unknown how the other conditions influence the relation between green space and social contacts.

\section{CONCLUSION}

It is widely recognised that social relationships can influence several health outcomes. Furthermore, there is increasing evidence for a positive relation between green space and health and there are indications of a positive relation between the amount of green space in the living environment and social relationships. However, it was unknown whether social contacts are a possible factor mediating the relation between green space and health.

This study indicates that the amount of green space in the living environment is not only related to people's health condition but is also positively related to people's feelings of loneliness and shortage of social support, especially for children, elderly, and people with a lower economic status. Furthermore, both feelings of loneliness and shortage of social support partially mediated between the relation between green space and health.

\section{ACKNOWLEDGMENTS}

This study was supported by a grant from the Netherlands Organisation for Scientific Research.

\section{REFERENCES}

Baron and Kenny, 1986 R.M. Baron and D.A. Kenny, The moderater-mediator variable distinction in social psychological research: conceptual, strategic, and statistical considerations, Journal of Personality and Social Psychology 51 (6) (1986), pp. 11731182.

Berkman et al., 2000 L.F. Berkman, T. Glass, I. Brisette and T.E. Seeman, From social integration to health. Durkheim in the new millennium, Social Science and Medicine 51 (2000), pp. 843-857.

Bridges et al., 2002 K.R. Bridges, R. Sanderman and F.L.P. Van Sonderen, An English language version of the social support list: preliminary reliability, Psychological Reports 90 (2002), pp. 1055-1058.

Coley et al., 1997 R.L. Coley, F.E. Kuo and W.C. Sullivan, Where does community grow? The social context created by nature in Urban Public Housing, Environment and Behaviour 29 (4) (1997), pp. 468-494.

de Jong Gierveld, 1998 J. de Jong Gierveld, A review of loneliness: concepts and definitions, determinants and consequences, Reviews in Clinical Gerontology 8 (1998), pp. 73-80.

de Vries et al., 2003 S. de Vries, R.A. Verheij, P.P. Groenewegen and P. Spreeuwenberg, Natural environments-healthy environments? An exploratory analysis of the relationship between greenspace and health, Environment and Planning A 35 (2003), pp. 1717-1731. De Wit and Clevers, 2004 A.J.W. De Wit and J.G.P.W. Clevers, Efficiency and accuracy of per-field classification for operational crop mapping, International Journal of Remote Sensing 25 (20) (2004), pp. 4091-4112. Den Dulk et al., 1992 C.J. Den Dulk, H. Van de Stadt and J.M. Vliegen, Een nieuwe maatstaf voor stedelijkheid: de omgevingsadressendichtheid, A new measure for degree of urbanisation: the address density of the surrounding area, Maandstatistiek van de Bevolking 7 (1992), pp. 14-22. Draper and Smith, 1998 N.R. Draper and H. Smith, III-conditioning in regression data, Applied Regression Analysis (third ed.), Wiley Series in Probability and Statistics, New York (1998), pp. 369-386.

Ewert and Heywood, 1991 A. Ewert and J. Heywood, Group development in the natural environment. Expectations, outcomes and techniques, Environmental and Behaviour 23 (5) (1991), pp. 592-615.Flap and Völker, 2005 H. Flap and B. Völker, Gemeenschap, informele controle en collectieve kwaden. In: B. Völker, Editor, Burgers in de buurt: samen leven in school, wijk en vereniging, Amsterdam University Press, Amsterdam (2005), pp. 41-70.

Foets and Van der Velden, 1990 M. Foets and J. Van der Velden, Een nationale studie van ziekten en verrichtingen in de huisartsenpraktijk. Basisrapport: meetinstrumenten en 
Maas, J., Dillen, S.M.E. van, Verheij, R.A., Groenewegen, P.P. Social contacts as a possible mechanism behind the relation between green space and health. Health and Place: 2009, 15(2), 586-595

procedures, A national study of morbidity and interventions in general practice. Basic report: measurement instruments and procedures, NIVEL, Utrecht (1990).

Goldberg, 1972 D.P. Goldberg, The Detection of Psychiatric Illness by Questionnaire, Oxford University Press, London (1972).

Groenewegen et al., 2006 P.P. Groenewegen, A.E. van den Berg, S. de Vries and R.A. Verheij, Vitamin G: effects of green space on health, well-being, and social safety, BMC Public Health 6 (149) (2006).

Hartig et al., 1991 T. Hartig, M. Mang and G.W. Evans, Restorative effects of natural environment experiences, Environment and Behavior 23 (1991), pp. 3-27.

Hartig et al., 2003 T. Hartig, G.W. Evans, L.D. Jamner, D.S. Davis and T. Garling, Tracking restoration in natural and urban field settings, Journal of Environmental Psychology 23 (2003), pp. 109-123. Hawe and Shiell, 2000 P. Hawe and A. Shiell, Social capital and health promotion: a review, Social Science and Medicine 51 (2000), pp. 871-885. Health Council of the Netherlands and Dutch Advisory Council for Research on Spatial Planning, 2004 Health Council of the Netherlands and Dutch Advisory Council for Research on Spatial Planning, Nature and Environment (RMNO), 2004. Nature and health. The influence of nature on social, psychological and physical well-being. Health Council of the Netherlands, RMNO, The Hague. (URL:Accessed 2008-05-27 (Archived by WebCite at

House et al., 1988 J.S. House, K.R. Landis and D. Umberson, Social relationships and health, Science 214 (1988), pp. 540-545. Kaplan and Kaplan, 1989 R. Kaplan and S. Kaplan, The Experience of Nature. A Psychological Perspective, Cambridge University Press, Cambridge (1989).

Kawachi and Berkman, 2000 I. Kawachi and L. Berkman, Social cohesion, social capital, and health. In: L. Berkman and I. Kawachi, Editors, Social Epidemiology, Oxford University Press, New York (2000).

Kawachi et al., 1997 I. Kawachi, B.P. Kennedy, K. Lochner and D. Prothrow-Stith, Social capital, income inequality, and mortality, American Journal of Public Health 87 (9) (1997), pp. 1491-1498. )

Kendler et al., 2005 K.S. Kendler, J. Myers and C. Prescott, Sex differences in the relationship between social support and risk for major depression: a longitudinal study of opposite-sex twin pairs, American Journal of Psychiatry 162 (2) (2005), pp. 250-256. Kim and Kaplan, 2004 J. Kim and R. Kaplan, Physical and psychological factors in sense of community: new urbanist Kentlands and nearby Orchard Village, Environment and Behavior 36 (3) (2004), pp. 313-340.

Koeter and Ormel, 1991 M.W.J. Koeter and J. Ormel, General Health Questionnaire. Nederlandse Bewerking, General Health Questionnaire. Dutch Edition, Swets \& Zeitlinger, Lisse (1991).

Kuo et al., 1998 F.E. Kuo, W.C. Sullivan and A. Wiley, Fertile ground for community: innercity neighbourhood common spaces, American Journal of Community Psychology 26 (1998), pp. 823-851.

Kweon et al., 1998 B.S. Kweon, W.C. Sullivan and A. Wiley, Green common spaces and the social integration of inner-city older adults, Environment and Behavior 30 (1998), pp. 823858.

Leyden, 2003 K.M. Leyden, Social capital and the built environment: the importance of walkable neighbourhoods, American Journal of Public Health 93 (9) (2003), pp. 1546-1551

Maas et al., 2006 J. Maas, R.A. Verheij, P.P. Groenewegen, S. de Vries and P.

Spreeuwenberg, Green space, urbanity and health: how strong is the relation?, Journal of Epidemiology and Community Health 60 (7) (2006), pp. 587-592.

Mitchell and Popham, 2007 R. Mitchell and F. Popham, Greenspace, urbanity and health: relationships in England, Journal of Epidemiological and Community Health 61 (2007), pp. 681-683. Preacher and Hayes, 2004 K.J. Preacher and A.F. Hayes, SPSS and SAS procedures for estimation indirect effects in simple mediation models, Behavior Research Methods, Instruments, and Computers 34 (4) (2004), pp. 717-731.

Pretty et al., 1994 G.M.H. Pretty, L. Andrewes and C. Collett, Exploring adolescents'sense of community and its relationship to loneliness, Journal of Community Psychology 22 (1994), pp. 346-358. 
Maas, J., Dillen, S.M.E. van, Verheij, R.A., Groenewegen, P.P. Social contacts as a possible mechanism behind the relation between green space and health. Health and Place: 2009, 15(2), 586-595

Prezza et al., 2001 M. Prezza, M. Amici, T. Roberti and G. Tedeschi, Sense of community referred to the whole town: its relations with neighboring, loneliness, life satisfaction, and area of residence, Journal of Community Psychology 29 (1) (2001), pp. 29-52.

Russell, 1996 D.W. Russell, UCLA loneliness scale (version 3): reliability, validity, and factor structure, Journal of Personality Assessment 66 (1) (1996), pp. 20-40.

Rütten et al., 2001 A. Rütten, T. Abel, L. Kannas, T. Von Lengerke, G. Lüschen, J.A. Rodriguez Diaz, J. Vinck and J. Van der Zee, Self reported physical activity, public health and perceived environment: results from a comparative European study, Journal of Epidemiology Community Health 55 (2001), pp. 139-146.

Simons, 2002 J.G. Simons, How is Your Health in General. Qualitative and Quantitative Studies on Self-Assessed Health and Socioeconomic Differences Herein, Erasmus University Rotterdam (2002).

Steenbekkers et al., 2006 C. Steenbekkers, A. Simon and V. Veldheer, Thuis op het platteland: de leefsituatie van platteland en stad vergeleken, Sociaal Cultureel Planbureau, Den Haag (2006).

Takano et al., 2002 T. Takano, K. Nakamura and M. Watanabe, Urban residential environments and senior citizens' longevity in megacity areas. The importance of walkable green spaces, Journal of Epidemiological Community Health 56 (2002), pp. 913-918.

Thunissen and De Wit, 2000 H.A.M. Thunissen and A.J.W. De Wit, The national land cover database of The Netherlands, ISPRS Journal of Photogrammetry and Remote Sensing 33 (2000).

Tijhuis, 1994 M.A.R. Tijhuis, Social Networks and Health, Netherlands Institute for Health Services Research (NIVEL), Utrecht (1994).

van Oostrom et al., 1995 M.A. van Oostrom, M.A.R. Tijhuis, J.C.J.M. de Haes, R. Tempelaar and D. Kromhout, A measurement of social support in epidemiological research: the social experiences checklist tested in a general population in The Netherlands, Journal of Epidemiological and Community Health 49 (1995), pp. 518-524.Van Sonderen, 1993a F.L.P. Van Sonderen, Het meten van sociale stuen met de Sociale Steun Lijst-Interacties (SSL-I) en Sociale Steun Lijst-Discrepanties (SSL-D): een handleiding, Measuring social support with the social support list: a manual, Noordelijk Centrum voor Gezondheidsvraagstukken, Groningen (1993).

Van Sonderen, 1993b Van Sonderen, F.L.P., 1993b. Social support list Van Sonderen and Ormel, 1997 F.L.P. Van Sonderen and J. Ormel, Het meten van aspecten van sociale steun en hun relatie met welbevinden. Een onderzoek naar de bruikbaarheid van de SSL-I en de SSL-D, Measuring aspects of social support and their relation with well-being. Research of the utility of the SSL-I and the SSL-D, Gedrag en Gezondheid 25 (4) (1997), pp. 190-200.

van Tilburg, 1998 T. van Tilburg, Losing and gaining in old age: changes in personal networks size and social support in a four-year longitudinal study, Journal of Gerontology Series B: Psychological Sciences and Social Sciences 53 (6) (1998), pp. S313-S323.

Völker et al., 2007 B. Völker, H.D. Flap and S. Lindenberg, When are neighbourhoods communities? Community in Dutch neighbourhoods, European Sociological Review 23 (1) (2007), pp. 99-114.

Westert et al., 2005 G.P. Westert, F.G. Schellevis, D.H. De Bakker, P.P. Groenewegen, J.M. Bensing and $\mathrm{J}$. van der Zee, Monitoring health inequalities through general practice: the second Dutch national survey of general practice, European Journal of Public Health 15 (1) (2005), pp. 59-65.

Wood et al., 2007 L. Wood, T. Shannon, M. Bulsara, T. Pikora, G. McCormack and B. GilesCorti, The anatomy of the safe and social suburb: an explanatory study of the built environment, social capital and residents' perceptions of safety, Health and Place (2007). 
Maas, J., Dillen, S.M.E. van, Verheij, R.A., Groenewegen, P.P. Social contacts as a possible mechanism behind the relation between green space and health. Health and Place: 2009, 15(2), 586-595

\section{TABLES}

Table 1

Descriptive statistics for the variables included in the analyses $(N=10,089)$

\begin{tabular}{|c|c|c|}
\hline & $\%(N)$ & $M$ (s.d.) (range) \\
\hline \multicolumn{3}{|l|}{ Demographic characteristics } \\
\hline \multicolumn{3}{|l|}{ Gender } \\
\hline Female & $54.9 \%(5538)$ & \\
\hline Male & $45.1 \%(4551)$ & \\
\hline \multicolumn{3}{|l|}{ Age } \\
\hline Children (12-17 years) & $8.8 \%(883)$ & \\
\hline Youth (18-25 years) & $7.7 \%(776)$ & \\
\hline Young adults (26-45 years) & $32.8 \%(3309)$ & \\
\hline Older adults (46-65 years) & $33.1 \%(3341)$ & \\
\hline Elderly $(>65$ years $)$ & $17.6 \%(1780)$ & \\
\hline $\begin{array}{l}\text { Number of people in } \\
\text { household }\end{array}$ & & 2.9 (1.4) (range 1-14) \\
\hline \multicolumn{3}{|l|}{ Socio-economic characteristics } \\
\hline \multicolumn{3}{|l|}{ Level of education } \\
\hline Level of education unknown & $12 \%(1206)$ & \\
\hline Low & $20.9 \%(2107)$ & \\
\hline Middle & $49.9 \%(5036)$ & \\
\hline High & $17.2 \%(1740)$ & \\
\hline \multicolumn{3}{|l|}{ Income } \\
\hline Unknown & $5.6 \%(56)$ & \\
\hline Low & $29.6 \%(2983)$ & \\
\hline Middle & $41.2 \%(4152)$ & \\
\hline High & $23.7 \%(2391)$ & \\
\hline \multicolumn{3}{|l|}{ Urbanicity } \\
\hline Very strongly urban & $15.9 \%(1609)$ & \\
\hline Strongly urban & $24.2 \%(2445)$ & \\
\hline Moderately urban & $20 \%(2013)$ & \\
\hline Sligthly urban & $29.9 \%(3014)$ & \\
\hline Non-urban & $10 \%(1008)$ & \\
\hline \multicolumn{3}{|l|}{ Percentage of green space } \\
\hline $\begin{array}{l}\text { Average percentage of green } \\
\text { space in a } 1 \mathrm{~km} \text { radius }\end{array}$ & & $\begin{array}{l}42.5 \%(\text { s.d. } 24.2) \text { (range } \\
.3-99.3 \text { ) }\end{array}$ \\
\hline $\begin{array}{l}\text { Average percentage of green } \\
\text { space in a } 3 \mathrm{~km} \text { radius }\end{array}$ & & $\begin{array}{l}60.7 \%(\text { s.d. } 21.6) \\
\text { (range 6.16-60.7) }\end{array}$ \\
\hline \multicolumn{3}{|l|}{ Dependent variables } \\
\hline \multicolumn{3}{|l|}{ Health } \\
\hline Percentage of healthy people & & $82.4 \%(8310)$ \\
\hline $\begin{array}{l}\text { Average number of } \\
\text { complaints }\end{array}$ & & 4.3 (s.d. 3.8$)$ \\
\hline $\begin{array}{l}\text { Self-rated propensity for } \\
\text { psychiatric morbidity }\end{array}$ & & $22.6 \%(2097)$ \\
\hline \multicolumn{3}{|l|}{ Social contacts } \\
\hline $\begin{array}{l}\text { Often contact with } \\
\text { neighbours }(n=4407)\end{array}$ & & $66.8 \%$ \\
\hline Loneliness $(n=10,089)$ & & $\begin{array}{l}7.5 \text { (s.d. 2) (range } \\
6-18)\end{array}$ \\
\hline $\begin{array}{l}\text { Number of supportive } \\
\text { interactions }(n=4842)\end{array}$ & & $\begin{array}{l}33.8 \text { (s.d. } 6.8 \text { ) (range } \\
19-65 \text { ) }\end{array}$ \\
\hline $\begin{array}{l}\text { Shortage of social support } \\
\qquad(n=4842)\end{array}$ & & $\begin{array}{l}21.3 \text { (s.d. 3.9) (range } \\
19-57 \text { ) }\end{array}$ \\
\hline
\end{tabular}


Maas, J., Dillen, S.M.E. van, Verheij, R.A., Groenewegen, P.P. Social contacts as a possible mechanism behind the relation between green space and health. Health and Place: 2009, 15(2), 586-595

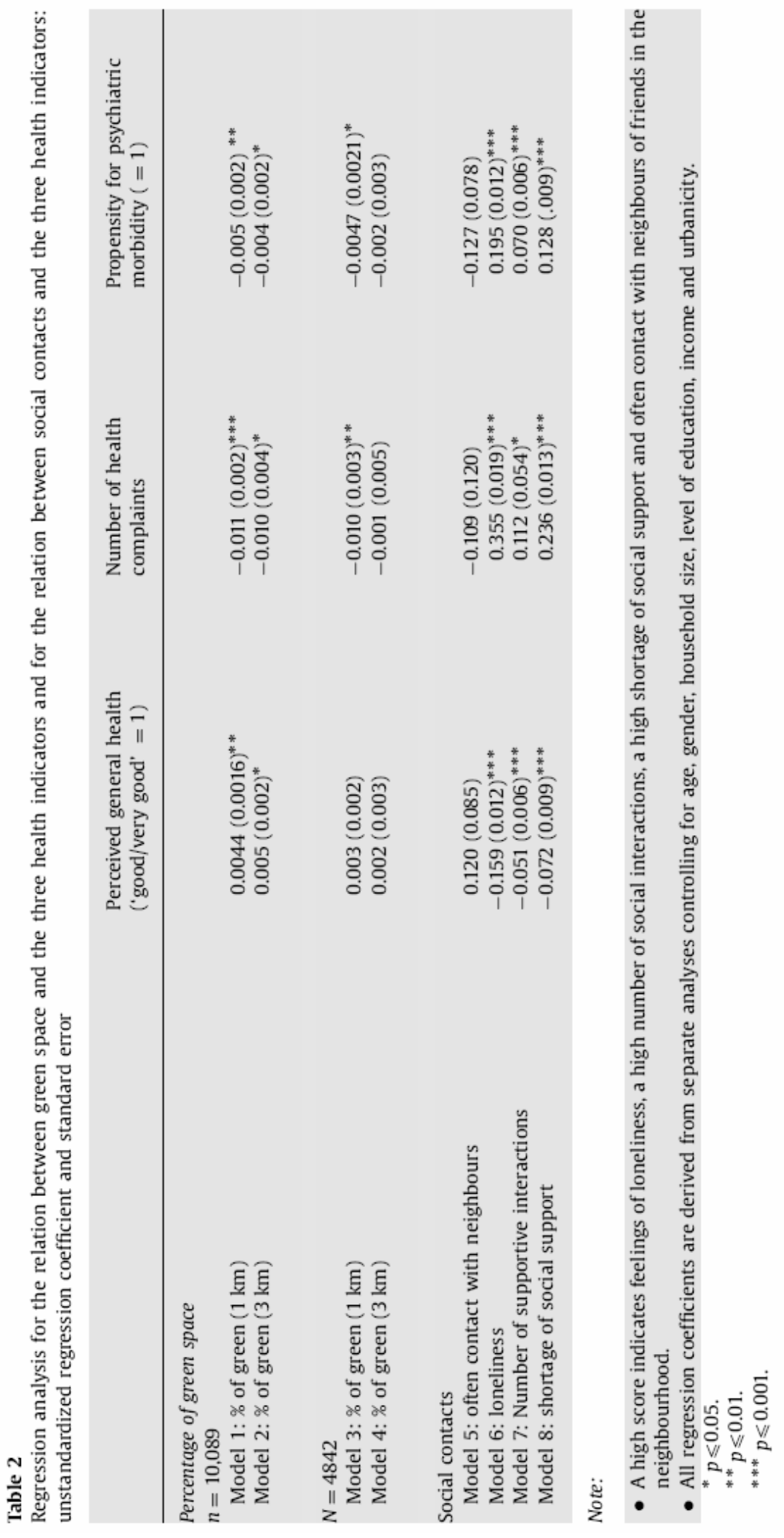


Maas, J., Dillen, S.M.E. van, Verheij, R.A., Groenewegen, P.P. Social contacts as a possible mechanism behind the relation between green space and health. Health and Place: 2009, 15(2), 586-595

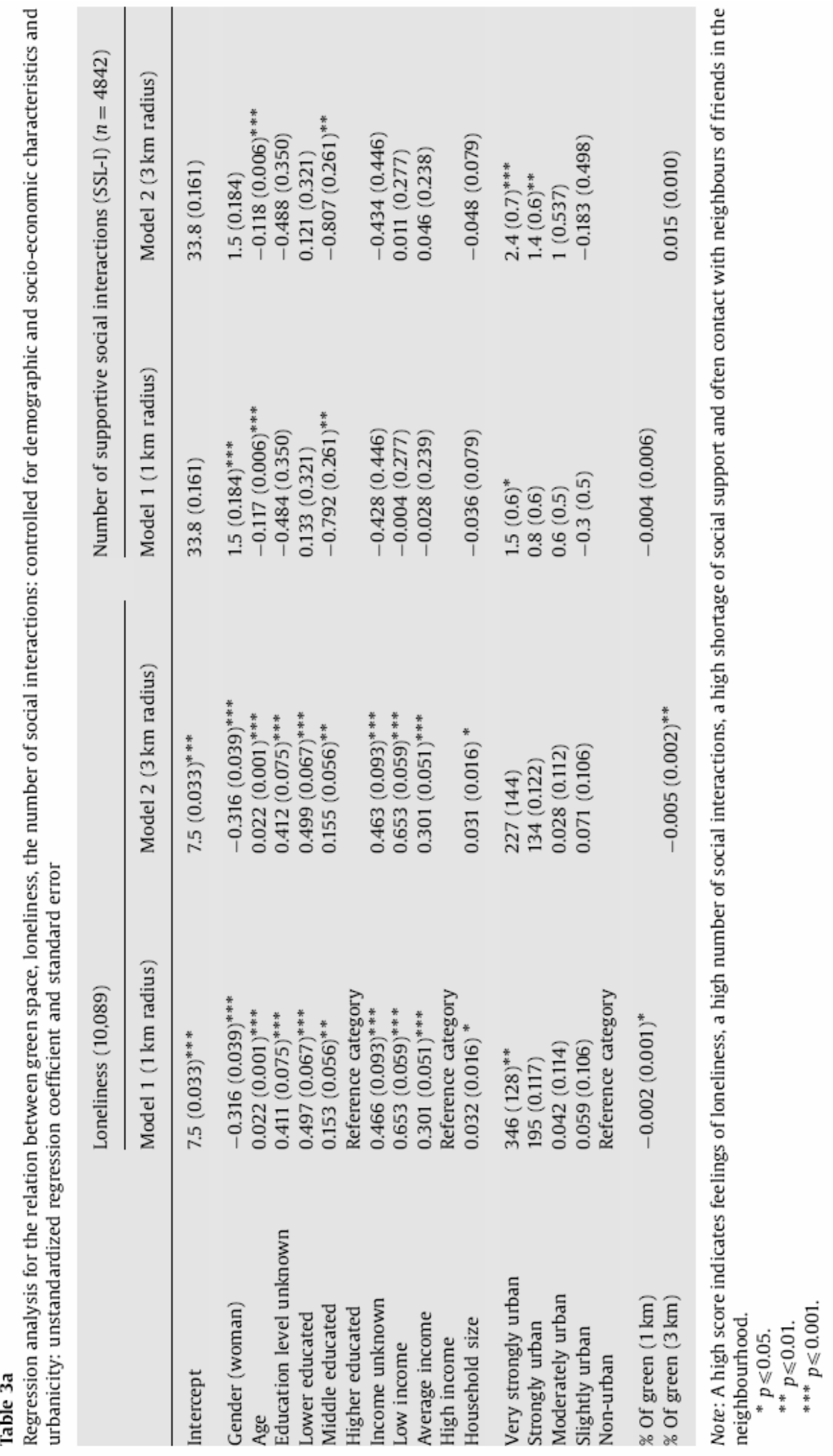


Maas, J., Dillen, S.M.E. van, Verheij, R.A., Groenewegen, P.P. Social contacts as a possible mechanism behind the relation between green space and health. Health and Place: 2009, 15(2), 586-595
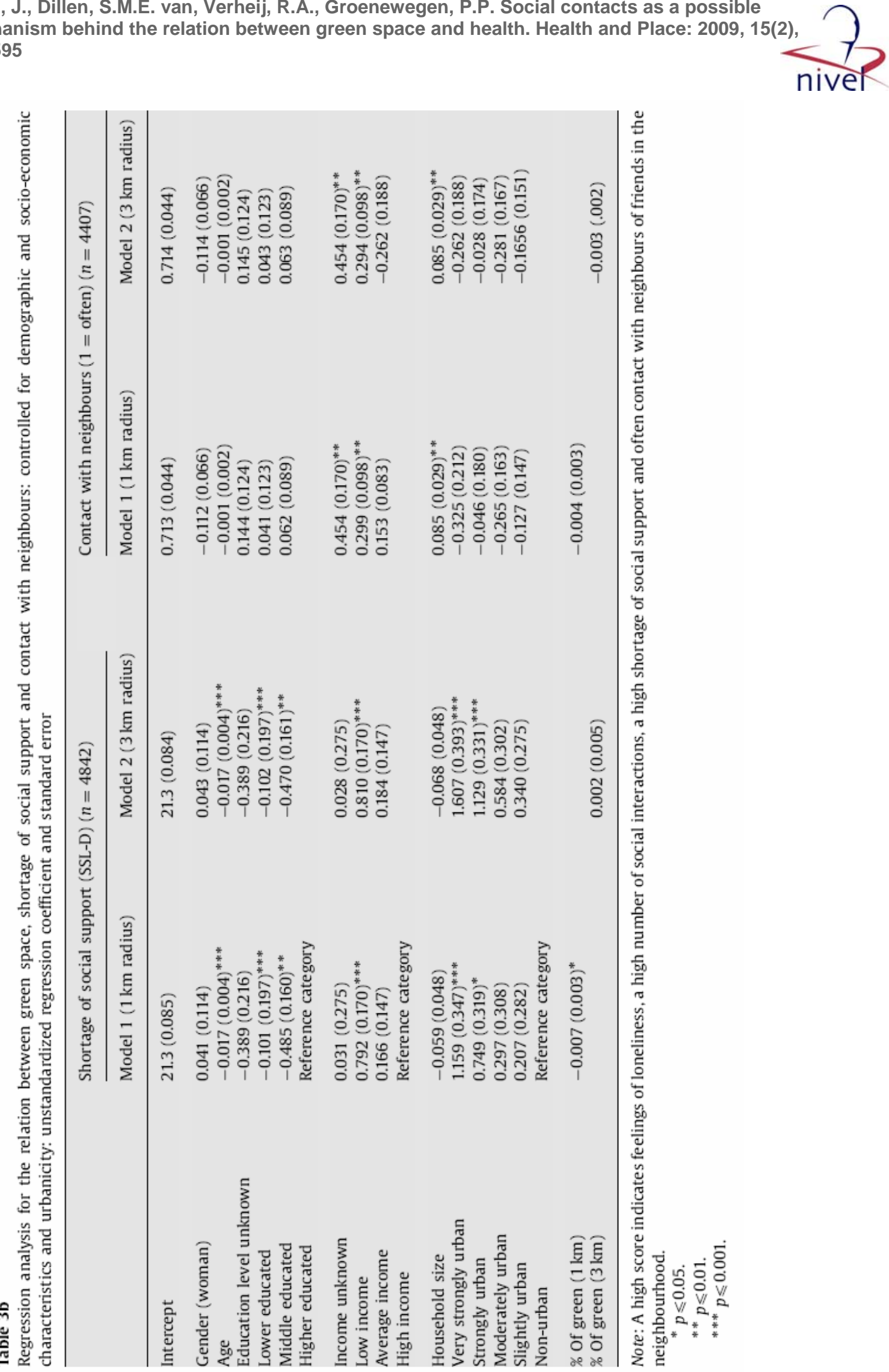
Maas, J., Dillen, S.M.E. van, Verheij, R.A., Groenewegen, P.P. Social contacts as a possible mechanism behind the relation between green space and health. Health and Place: 2009, 15(2), 586-595

\section{Table 4}

Relation between green space and different social relationship indicators controlled for demographic and socio-economic characteristics and urbanicity: unstandardized regression coefficient and standard error

\begin{tabular}{|c|c|c|}
\hline & $\begin{array}{l}\text { Loneliness } \\
(n=10,089)\end{array}$ & $\begin{array}{l}\text { Shortage of social } \\
\text { support }(n=4842)\end{array}$ \\
\hline \multicolumn{3}{|l|}{ Model 1} \\
\hline $\begin{array}{l}\% \text { Of green }(1 \mathrm{~km}) \times \text { very strongly } \\
\text { urban }\end{array}$ & $0.004(0.003)$ & $-0.007(0.010)$ \\
\hline$\%$ of green $(1 \mathrm{~km}) \times$ strong & $-0.007(0.002)^{* * *}$ & $-0.019(0.007)^{*}$ \\
\hline$\%$ of green $(1 \mathrm{~km}) \times$ moderately & $-0.003(0.003)$ & $0.001(0.007)$ \\
\hline$\%$ of green $(1 \mathrm{~km}) \times$ slightly & $-0.000(0.002)$ & $-0.006(0.006)$ \\
\hline$\%$ of green $(1 \mathrm{~km}) \times$ non-urban & $-0.004(0.004)$ & $-0.005(0.012)$ \\
\hline \multicolumn{3}{|l|}{ Model 2} \\
\hline$\%$ of green $(3 \mathrm{~km}) \times$ very strong & $0.000(0.004)$ & \\
\hline$\%$ Of green $(3 \mathrm{~km}) \times$ strong & $-0.009(0.004)^{*}$ & \\
\hline$\%$ Of green $(3 \mathrm{~km}) \times$ moderately & $-0.004(0.004)$ & \\
\hline$\%$ Of green $(3 \mathrm{~km}) \times$ slightly & $-0.004(0.004)$ & \\
\hline$\%$ Of green $(3 \mathrm{~km}) \times$ non-urban & $-0.009(0.006)$ & \\
\hline \multicolumn{3}{|l|}{ Model 3} \\
\hline$\%$ Of green $(1 \mathrm{~km}) \times$ children & $-0.004(0.002)^{*}$ & $-0.021(0.007)^{* *}$ \\
\hline$\%$ of green $(1 \mathrm{~km}) \times$ youth & $-0.001(0.002)$ & $-0.014(0.006)^{*}$ \\
\hline$\%$ Of green $(1 \mathrm{~km}) \times$ young adults & $-0.002(0.001)^{*}$ & $-0.003(0.004)$ \\
\hline$\%$ of green $(1 \mathrm{~km}) \times$ older adults & $-0.0021(0.001)$ & $-0.003(0.004)$ \\
\hline$\%$ of green $(1 \mathrm{~km}) \times$ elderly & $-0.003(0.002)$ & $-0.019(0.005)^{* * *}$ \\
\hline \multicolumn{3}{|l|}{ Model 4} \\
\hline$\%$ of green $(3 \mathrm{~km}) \times$ children & $-0.006(0.002)^{*}$ & \\
\hline$\%$ Of green $(3 \mathrm{~km}) \times$ youth & $-0.004(0.002)$ & \\
\hline$\%$ of green $(3 \mathrm{~km}) \times$ young adults & $-0.004(0.002)^{*}$ & \\
\hline$\%$ of green $(3 \mathrm{~km}) \times$ older adults & $-0.005(0.002)^{*}$ & \\
\hline$\%$ Of green $(3 \mathrm{~km}) \times$ elderly & $-0.005(0.002)^{*}$ & \\
\hline \multicolumn{3}{|l|}{ Model 5} \\
\hline $\begin{array}{l}\% \text { Of green }(1 \mathrm{~km}) \times \text { lower } \\
\text { educated }\end{array}$ & $-0.008(0.002)^{* * *}$ & $-0.009(0.006)$ \\
\hline $\begin{array}{l}\% \text { Of green }(1 \mathrm{~km}) \times \text { middle } \\
\text { educated }\end{array}$ & $-0.002(0.001)$ & $-0.004(0.004)$ \\
\hline$\%$ of green $(1 \mathrm{~km}) \times$ high educated & $0.003(0.002)$ & $-0.009(0.006)$ \\
\hline \multicolumn{3}{|l|}{ Model 6} \\
\hline $\begin{array}{l}\% \text { Of green }(3 \mathrm{~km}) \times \text { lower } \\
\text { educated }\end{array}$ & $-0.012(0.003)^{* * *}$ & \\
\hline $\begin{array}{l}\% \text { Of green }(3 \mathrm{~km}) \times \text { middle } \\
\text { educated }\end{array}$ & $-0.006(0.002)^{*}$ & \\
\hline$\%$ of green $(3 \mathrm{~km}) \times$ high educated & $0.002(0.003)$ & \\
\hline \multicolumn{3}{|l|}{ Model 7} \\
\hline$\%$ of green $(1 \mathrm{~km}) \times$ Low income & $-0.006(0.002)^{* *}$ & $-0.019(0.005)^{* * *}$ \\
\hline$\%$ of green $(1 \mathrm{~km}) \times$ middle income & $-0.001(0.002)$ & $-0.003(0.005)$ \\
\hline$\%$ Of green $(1 \mathrm{~km}) \times$ high income & $0.001(0.002)$ & $0.001(0.005)$ \\
\hline \multicolumn{3}{|l|}{ Model 8} \\
\hline$\%$ of green $(3 \mathrm{~km}) \times$ low income & $-0.008(0.002)^{* *}$ & \\
\hline$\%$ Of green $(3 \mathrm{~km}) \times$ middle income & $-0.003(0.002)$ & \\
\hline$\%$ Of green $(3 \mathrm{~km}) \times$ high income & $-0.002(0.003)$ & \\
\hline
\end{tabular}

Note: A high score indicates feelings of loneliness and a high shortage of social support. All models were controlled for age, gender, household size, level of education, income and urbanicity.

$$
\begin{aligned}
& { }^{*} p \leqslant 0.05 . \\
& { }^{* *} p \leqslant 0.01 . \\
& { }^{* * * *} p \leqslant 0.001 \text {. }
\end{aligned}
$$


Maas, J., Dillen, S.M.E. van, Verheij, R.A., Groenewegen, P.P. Social contacts as a possible mechanism behind the relation between green space and health. Health and Place: 2009, 15(2), 586-595

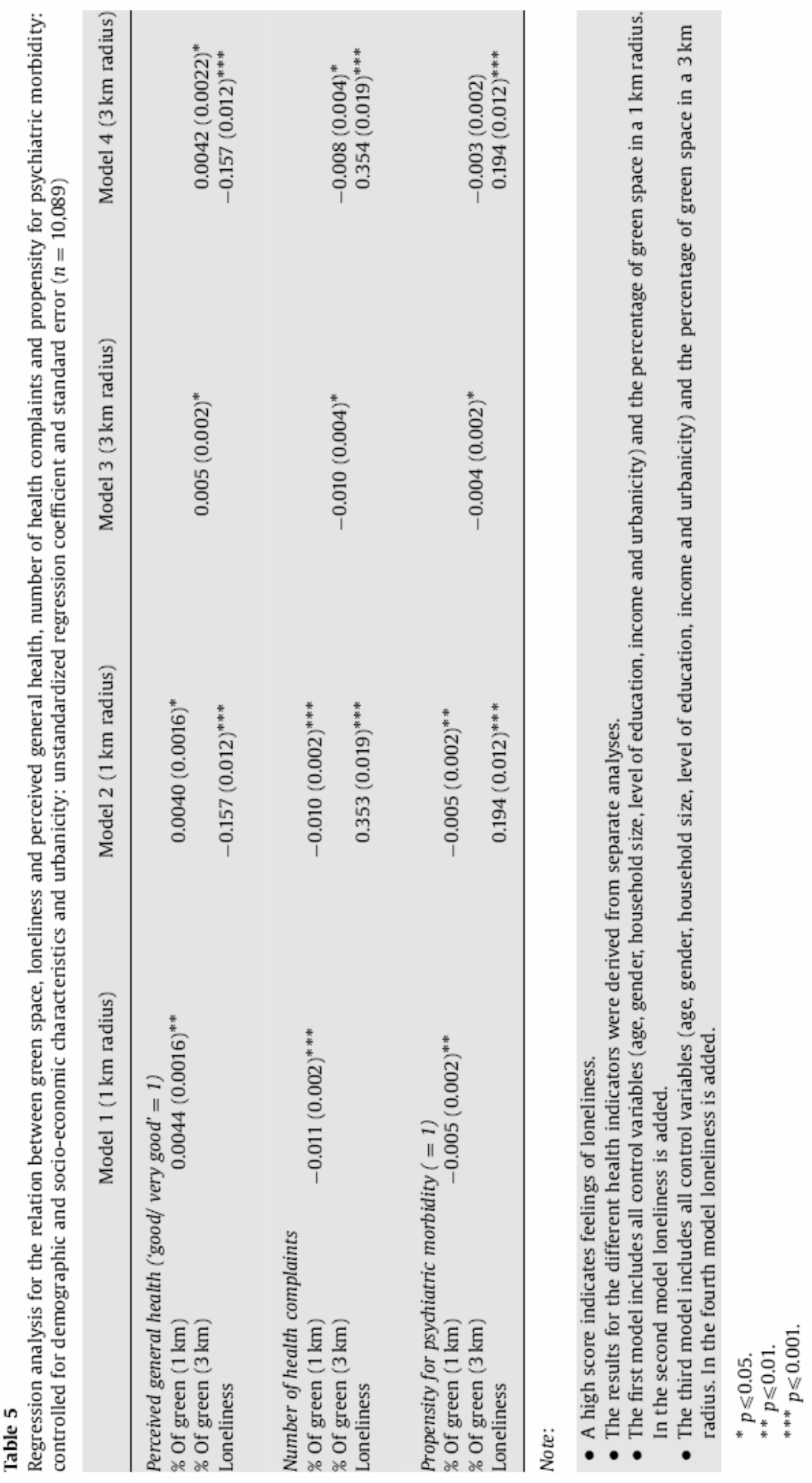


Maas, J., Dillen, S.M.E. van, Verheij, R.A., Groenewegen, P.P. Social contacts as a possible mechanism behind the relation between green space and health. Health and Place: 2009, 15(2), 586-595

\section{Table 6}

Regression analysis for the relation between green space, shortage of social support and number of health complaints and propensity for psychiatric morbidity: controlled for demographic and socio-economic characteristics and urbanicity: unstandardized regression coefficient and standard error $(n=4842)$

\begin{tabular}{|c|c|c|}
\hline & Model 1 & Model 2 \\
\hline $\begin{array}{l}\text { Number of health complaints } \\
\% \text { Of green }(1 \mathrm{~km}) \\
\text { Shortage of social support }\end{array}$ & $-0.010(0.003)^{* *}$ & $\begin{array}{r}-0.008(0.003)^{* *} \\
0.235(0.013)^{* * *}\end{array}$ \\
\hline $\begin{array}{l}\text { Propensity for psychiatric mo } \\
\% \text { Of green }(1 \mathrm{~km}) \\
\text { Shortage of social support }\end{array}$ & $\begin{array}{l}(=1) \\
-0.0047(0.0021)^{*}\end{array}$ & $\begin{array}{r}-0.0038(0.0021) \\
0.128(0.009)^{* * * *}\end{array}$ \\
\hline
\end{tabular}

Note:

- A high score indicates a high shortage of social support.

- The results for the different health indicators were derived from separate analyses.

- The first model includes all control variables (age, gender, household size, level of education, income and urbanicity) and the percentage of green space in a $1 \mathrm{~km}$ radius. In the second model shortage of social support is added.

$* p \leqslant 0.05$.

** $p \leqslant 0.01$.

$* * * p \leqslant 0.001$. 